\title{
The Lack of Physics Teachers: "Like a Bath with the Plug out and the Tap half on"
}

\author{
Isaac Buabeng* , Lindsey Conner, David Winter \\ College of Education, Health and Human Development, University of Canterbury, New Zealand \\ *Corresponding author: isaac.buabeng@pg.canterbury.ac.nz, ibuabeng@ucc.edu.gh
}

Received April 27, 2015; Revised May 14, 2015; Accepted May 21, 2015

\begin{abstract}
In this study, we were interested in how approaches to teaching high school physics in New Zealand influenced students' perceptions of physics and their consequent desire to continue with physics. We also investigated the reasons participants became physics teachers to inform how more teachers might be attracted into the profession. The convergent parallel design of this study used mixed methods including a national survey as well as classroom observations and interviews with teachers and students. The study has identified how a focus on content knowledge and more "traditional" teaching approaches tends to discourage students to progress with physics.
\end{abstract}

\section{Keywords: classroom practices, teaching strategies, physics teachers, physics students}

Cite This Article: Isaac Buabeng, Lindsey Conner, and David Winter, "The Lack of Physics Teachers: "Like a Bath with the Plug out and the Tap half on”.” American Journal of Educational Research, vol. 3, no. 6 (2015): 721-730. doi: 10.12691/education-3-6-9.

\section{Introduction}

There is a global concern about the number of students pursuing physics at both secondary and tertiary levels and the number of graduates wanting to be trained as physics teachers (Institute of Physics [IOP], 2010; PhysTEC, 2014). In 2013, the National Task Force on Teacher Education reported that "the need for qualified physics teachers is greater now than at any previous time in U.S. history." (PhysTEC, 2014). The decline in interest in the subject has led to the closure of some physics departments at universities (Blickenstaff, 2010). This decline in the numbers of students taking physics could be due to a combination of factors including the perception that physics is a 'hard' subject with low levels of student achievement; the perceived nature of the subject as being highly mathematical and abstract; and how the subject is taught at the high school level. We therefore investigated this as part of the study.

In 1996, in the USA, the National Research Council's National Science Education Standards put forward five assumptions about science teaching, including the belief that, "What students learn is greatly influenced by how they are taught” (National Research Council, 1996, p. 28). Moreover, in the same year the standards called for a pedagogical shift from a teacher-centered to a studentcentered instructional paradigm. It was held that a more student-centered approach to learning engages students in socially interactive scientific inquiry and facilitates lifelong learning. Also, there is considerable evidence to suggest that a move towards pedagogies involving full interaction, collective reflection and the development of consensual knowledge would lead to improved learning and attainment (Conner, 2014a; Darling-Hammond \& Baratz-Snowden, 2005; Moraru, Stoica, \& Popescu, 2011; Smart \& Marshall, 2012).

Researchers over the years have maintained that teachers form a strong causal factor in defining the quality of education in schools (Archibald, 2006; DarlingHammond \& Baratz-Snowden, 2005; Golla, de Guzman, Ogena, \& Brawner, 1998; Hake, 1998). Teachers see to it that students have acquired creative and critical thinking abilities ready to face the realities of life. Central to acquiring creative and critical thinking abilities is the ability of teachers to design teaching sequences that develop among their students the abilities to respond to situations that make their learning meaningful (DarlingHammond \& Baratz-Snowden, 2005). This suggests that teacher's abilities to create an enabling atmosphere that allows meaningful classroom interaction with students is very important. More so, the types of classroom interactions created by the teacher and the types of questions he/she uses to structure the teaching skills play an important role in the kinds of thinking skills learners employ, the range of information to be covered and the thinking skills they may learn (Darling-Hammond \& Baratz-Snowden, 2005; Smart \& Marshall, 2012).

Likewise, at the heart of physics education research is a shift in physics instruction from concentrating on teaching to focussing on students' learning. In order to make this shift achievable, Redish and Steinberg (1999) stressed that teachers of physics need to listen to students and find ways to help students learn physics through making their courses meaningful. McDermott (2001) extols that the focus of physics teaching must be on the students as learners. She emphasises that effective teaching includes close contact with students where teachers observe the struggles of students as they try to understand important 
concepts and principles. Further, McDermott's research indicates that different instructional strategies have different effects on students' learning (McDermott, 2001). What teachers need to understand is that conceptual learning of physics often uses models, animations and simulations for problem solving approaches - Physics by Inquiry (Afra, Osta, \& Zoubeir, 2009; Akerson, Hanson, \& Cullen, 2007; Campbell, Danhui, \& Neilson, 2011). The advances in computer hardware and software programs have provided new platforms for instigating conceptual change and problem solving which physics teachers should tap into it (Dünser, Walker, Horner, \& Bentall, 2012; Ülen \& Gerlič, 2012; Wieman, Perkins, \& Adams, 2008). These platforms, for example Applet,PhET and BuildAR provide opportunity for students to interact with the virtual world by changing conditions and immediately observing the results. When students are actively engaged in learning in these types of ways, they are more likely to be interested and potentially learn more effectively (Dünser et al., 2012; Pedersen, 2011; Tversky, Morrison, \& Betrancourt, 2002; Ülen \& Gerlič, 2012)

Generally, teachers' beliefs about teaching have potential influence on their teaching practice (LoucksHorsley, Stiles, Mundry, Love, \& Hewson, 2010). What people know and believe influences their actions and informs the choices they make every day. In particular, the approaches used by physics teachers to teach physics are generally linked to their views or beliefs about physics as a body of knowledge (Koballa, Glynn, \& Upson, 2005; McDermott \& Shaffer, 2000). Koballa et al. (2005) argued that teachers' beliefs about teaching are most often reflected in their practice and thus influence their instructional decision-making. McDermott and Shaffer (2000) and Blanton (2003) also observed that teachers of science often teach in the way they have been taught. If they were taught through lectures, they are likely to lecture, even if this type of instruction is inappropriate for their students. Again, Ladachart (2011) found that physics teachers had developed conceptions about teaching based on their previous experiences at school, both as students and as pre-service teachers.

Mulhall and Gunstone (2008, 2012) used qualitative methodology to explore views about physics held by a group of physics teachers whose teaching practice was traditional, and compared these with the views held by physics teachers who used conceptual change approaches. Through semi-structured interviews and observations, Mulhall and Gunstone (2008, p. 444) discussed that:

The Traditional teachers thought of physics learning as the outcome of doing certain activities, and in terms of acquisition of information about physics ideas. For the traditional teachers, physics was seen as hard because it is mathematical and abstract, and many learners do not have the special attributes necessary to learn it. The conceptual teachers thought that learning involves cognitive activity by the learner, and that individuals construct their own understanding in terms of their personal frameworks. For the conceptual teachers, the ideas of physics were considered to be counter-intuitive and troublesome in terms of learning. They saw discussion as being important for learners as it helps tease out and develop understandings of physics ideas. (Mulhall \& Gunstone, 2012, p. 444).

\subsection{Previous Research - Nature of Physics Classroom Practices}

Even though many empirical studies have demonstrated that carefully planned, interactive instruction can be effective in promoting conceptual change and enhance performance (Cahyadi, 2007; McDermott \& Redish, 1999; Redish \& Steinberg, 1999; Thacker, 2003; Vosniadou, 2007; Wieman et al., 2008), findings from the literature show that many physics teachers continue to teach using an ineffective, traditional, teacher-centred instructional approach (Angell, Guttersrud, Henriksen, \& Isnes, 2004; Gallagher, 1991; Hackling, Goodrum, \& Rennie, 2001; Tobin \& Gallagher, 1987; Vosniadou, 2007).

For instance in the late eighty's in Perth Australia, Tobin and Gallagher (1987) found that the common instructional mode in high school science classes was whole class interactive - when the teacher dealt with the class as a whole, and interacted with one student at a time while the others listened; and whole class non-interactive - comprised of lecture presentations followed by individual seatwork and small group activities. More than a decade after, Hackling et al. (2001) found that the teacher-centred instructional approach was still prevalent in many of the secondary schools in Australia:

For many secondary students, the teaching-learning process is teacher directed and lessons are of two main types: practical activities where students follow the directions of the teacher to complete an experiment, and the chalk and talk lesson in which learning is centred on teacher explanation, copying notes and working from an expository text. (Hackling et al., 2001, p. 8)

In Hackling et al's study, the extent of teachercentredness was reported by $61 \%$ of secondary students who indicated that they copied notes from the teacher nearly every lesson. As well, 59\% of students indicated that the teacher never allowed them to choose their own topics to investigate.

A similar situation was described in high schools in Norway. Angell et al. (2004) administered questionnaires to 2192 students taking physics and 342 physics teachers in high schools in Norway, followed by interviews. They found that proportionally a greater part of classroom time (about 60\%), in relation to physics, was spent with the teacher presenting new material on the blackboard/whiteboard. Physics classrooms were dominated by "chalk and talk instruction" (p. 701). Though students in the study perceived physics as interesting and related to everyday phenomena, they also perceived the subject as difficult/demanding, formalistic in nature and more mathematical. The majority of the students wanted stronger emphasis on context and connectedness as well as qualitative/conceptual approaches and more student-centred approaches. Based on the findings, the authors suggested that:

“...secondary physics education preparing students for tomorrow's society should be characterized by variety, both within and among courses, integration of mathematics in the physics courses, more pupil-centred instruction, and a stronger emphasis on knowledge in context. (p. 703)

It has also been shown that interactions affect learners attitudes towards learning and their participation in class 
activities (Masika, 2011). Masika indicated that teacher interaction behaviours were an important aspect of the learning environment and were strongly related to high school student outcomes. Masika found that, in Kenya, physics teachers were autocratic and dominated their classrooms by either talking or talking with illustrations. One can infer from the above studies that teacher-centred instruction continues to be a widely used instructional strategy in secondary school physics classrooms. Moreover, students have expressed a desire for more interactive environments. If traditional approaches to teaching physics, which often fail to promote adequate student understanding of physics concepts, still persist (Angell et al., 2004; Hackling et al., 2001; Masika, 2011; Mulhall \& Gunstone, 2008, 2012) then there is a huge challenge to promote pedagogical change so that physics teachers teach for better student learning.

\subsection{Context of this Study}

Science is one of the eight learning areas that the New Zealand Curriculum (NZC) specifies as important for a broad, general education for every child (Ministry of Education, 2007). In the science learning area, students are expected to explore both how the natural physical world and science itself work so that they can participate as "critical, informed and responsible citizens in a society in which science plays a significant role" (Ministry of Education, 2007, p. 17). In addition, the NZC describes five key competencies as directions for learning - thinking; communication (using language, symbols and text); managing self; relating to others; and participation and contributing which align with the $21^{\text {st }}$ century learning skills - integration of information technology, and developing children's skills in collaboration, communication, critical thinking and creative problem solving (Conner, 2014b).

The NZC defines effective pedagogy as "teacher actions that promote student learning” (Ministry of Education, 2007, p. 34). The NZ education context requires schools to design their own learning programmes to meet the needs of their communities and students (Education Review Office, 2012; Ministry of Education, 2007). The NZC emphasises the importance of creating and encouraging reflective thought and action; enhancing relevance; facilitating shared learning; making connections to prior learning and experience; providing sufficient opportunities to learn; and inquiring into the teaching and learning relationship. All these are key elements of inquiry-based learning. Thus, when students are taught by inquiry, individuals are actively engaged with others in attempting to understand and interpret phenomena for themselves thereby improving performance. Our study used mixed methods to answer the following questions:

1. Why did teachers become physics teachers?

2. How do approaches to teaching and learning affect students' perceptions of physics?

3. What changes do secondary teachers and students perceive need to occur to make physics more interesting to learn?

4. What were students saying about why they would or would not become physics teachers?

\section{Theoretical Framework}

The study was underpinned by the constructivist theory. Constructivism is characterized by the view that knowledge is not transmitted directly from one person to another, but is actively built up by the learner (Cobern, 1998; Driver, Asoko, Leach, Scott, \& Mortimer, 1994). Conner (2014a) also accentuates that a constructivist classroom is a learner-centred environment which acknowledges and brings to the fore the past experience of students. She articulates that in constructivist classrooms, learning is "reflective, interactive, inductive and collaborative, and questions are valued as a source for curiosity and focus for finding out information” (p. 3). Constructivism as a theory, has evolved from not only learning about declarative knowledge (knowing what) but also knowing "how and when" to learn in different ways (Conner, 2014a). In such classrooms, accordingly, the teacher acts as a facilitator or mediator of learning rather than someone who only takes on the role of imparting knowledge.

\section{Methodology}

\subsection{Design}

Mixed methods were used and included a national survey of 104 physics teachers throughoutNew Zealand, students' survey, and interviews with 82 physics high school students. Specifically, the convergent parallel design (Creswell \& Clark, 2011) was employed for this study. The teachers' survey identified their current views on classroom practices, perceptions about what limits the quality of physics teaching and learning, and how teaching and learning of physics could be improved. The students' survey gathered students' views about their experiences in physics classrooms, their competencies and challenges, and what would motivate them to learn physics and possibly to become physics teachers. Focus group interviews with physics students and individual physics teachers provided supplementary data.

If a study uses different research methodologies, for example quantitative and qualitative methods, it has the advantage of helping the researcher gain a deeper understanding of certain issues pertaining to the problem under investigation (Best \& Kahn, 2005; Cohen, Manion, \& Morrison, 2007; Taylor, 2004). Again, as Gray (2009) noted, "people may articulate a particular view, but in practice behave differently” (p. 221). Triangulation and comparison of data from multiple sources therefore lead to trustworthiness and to the credibility of interpretation (Bogdan \& Biklen, 2007; Cohen et al., 2007; Keser, Akdeniz, \& Yyu, 2010; Sarantakos, 2005; Yin, 2009). Likewise, it enables researchers to delve deeper into issues that it might not be possible to explore using questionnaires alone (Fraenkel, Wallen, \& Hyun, 2012).

\subsection{Instruments and Procedure}

An online survey questionnaire and semi-structured interview protocols were developed for the study. Two forms of both closed and open-ended questionnaires were developed and used for data collection. These were the Physics Teachers' Questionnaire (PTQ) and Physics Students' Questionnaire (PSQ). Both the PTQ and PSQ were adapted from existing surveys for evaluating 
secondary schools science and mathematics classrooms (Angell et al., 2004; Hackling et al., 2001; Weiss, Banilower, McMahon, \& Smith, 2001). The questionnaire asked both Physics teachers and students to indicate on a five-point Likert scale (with extreme alternatives of Never - Always) how often a number of teaching strategies and practices occur in their physics classrooms. Students were also asked to indicate how often they would like these strategies and practices to be applied. The practices were grouped under the following subheadings: teaching approaches, teacher feedback and guidance, and ICT usage in physics teaching. We triangulated the findings from the survey with in-depth interviews with four teachers. Focus group interviews with senior (Year 12 and 13) physics students were also conducted. Fourteen focus group interviews were conducted with a total of 82 students. Ethical approval for this study was obtained from the University of Canterbury Human Ethics in Research Committee.

The semi-structured interview protocols for physics teachers and students were designed to gather data in the participants' own words (Fraenkel et al., 2012). As May (2001) noted: "the interviewer can seek both clarification and elaboration on the answers given and thus enter into a dialogue with the interviewee" (p. 123). The semistructured method also allows the researcher to raise issues of particular concern to the study (Fraenkel et al., 2012). Further questions, which were not expected at the commencement of the interview, could also be asked as new issues arose (Gray, 2009).

\subsection{Data Analysis}

Data from teachers and student survey questionnaires were analysed using descriptive statistical methods, including percentages, means, standard deviations and graphs where appropriate. Audio recordings from interviews were listened to several times and transcribed. Nvivo 10 for Windows (QSR International Pty Ltd. Version 10, 2012) was used to organize the materials by coding them into nodes which provided easy retrieval of the themes that emerged. Our analysis is given in terms of the data gathered from teachers and students' responses. Where quotes are used, these are representative of the statements of many teachers and students. The production of accurate and verbatim transcript is integral to establishing the credibility and trustworthiness of the data (Lewis-Beck, Bryman, \& Liao, 2004).

\section{Results}

\subsection{Why Teachers Became Physics Teachers}

Physics was a first-choice teaching subject for about three quarters of the teachers surveyed. Reasons cited for becoming physics teachers fell into the following categories: personal interest; family background; an encounter with an inspiring physics teacher; and access to a teacher scholarship scheme. The summary of teacher responses is presented in Figure 1.

As seen in Figure 1, the majority of the teachers (43.3\%) became physics teachers through scholarship schemes that were instituted specifically for the training of physics teachers due to a shortage at that time. A financial incentive was offered to them to become physics teachers, improving upon their existing remuneration. One teacher remarked:

...and at that time they had a scheme to encourage physics graduates into teaching because there was a shortage at that time (1979), and so I was offered more money to train as a teacher than I was getting from my previous job.

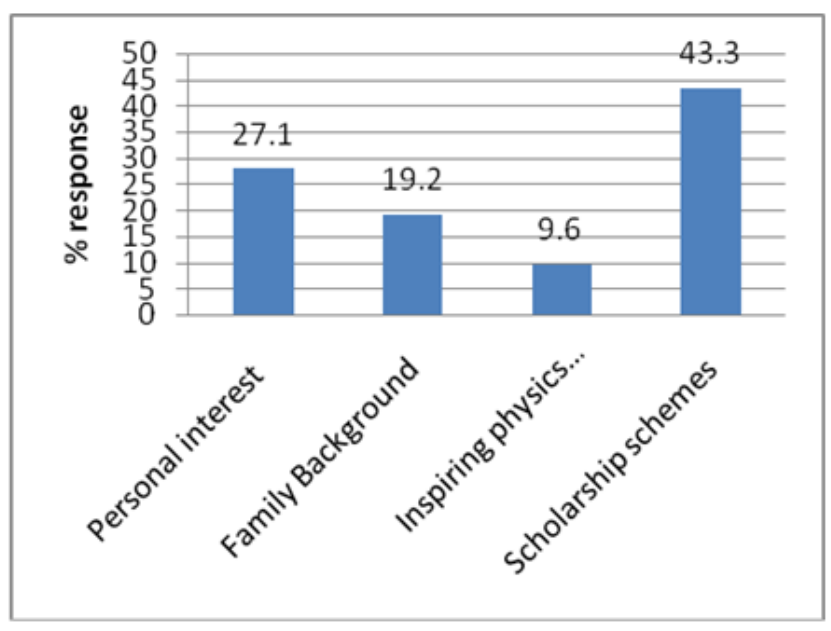

Figure 1. Reasons why teachers became physics teachers

About $27 \%$ of the teachers emphasized that they had always wanted to teach, and because they excelled at physics and mathematics and/or did a physics related course at university, they became physics teachers. Only a few (about 10\%) remarked that a previous physics teacher was influential in their decisions to enter teaching. Most completed a one-year post graduate diploma in Education at a university or participated in a conjoint degree programme to become physics teachers.

Figure 2 shows that about one quarter of the teachers had switched to physics from another subject in the course of their teaching career. Their reasons for doing so were explored and fell into one of three categories: a lack of physics teachers/subject specialists; job availability; and interest in the subject.

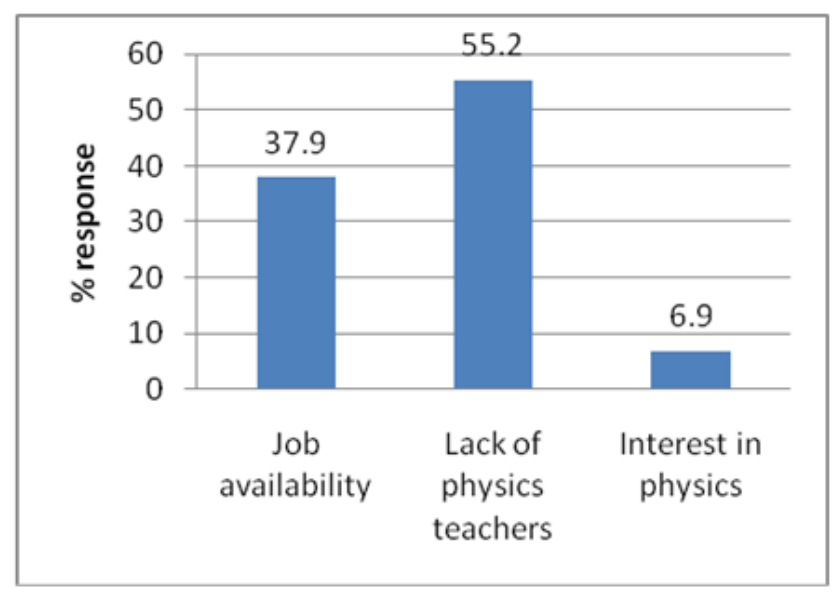

Figure 2. Teachers' reasons for switching to physics

The main reason (about 55\%) why the teachers changed to physics was a lack of physics teachers/subject specialists to teach the subject. Job availability was the next most popular reason (about $40 \%$ ) mentioned by the teachers. 


\subsection{Approaches to Teaching and Learning of Physics}

In order to find out what happens in physics classrooms and what effect this has on students' perceptions of physics, both physics teachers and students were asked to indicate on a five-point Likert scale (with extreme alternatives of Never - Always) how often particular teaching strategies and practices occur in their physics classrooms. Students were also asked to indicate how often they would like these strategies and practices to be applied. The practices were grouped under the following sub-headings: teaching approaches; teacher feedback and guidance; and ICT usage in physics teaching. Responses were coded and ranked on a five-point Likert scale format with 'Never'=1; 'Not Often'=2; 'Sometimes'=3; 'Most of the Time'=4; and 'Always'=5. The findings of the physics teacher's responses to the rating-scale items are reported in Table 1, Table 2 and Table 3. The findings from the students' responses are presented in Figure 3, Figure 4 and Figure 5.

Table 1. Means and standard deviations of items on Teaching Approaches

\begin{tabular}{lll}
\hline Statements & Mean & 3.55 \\
\hline I present new materials on white board & 3.89 & 0.88 \\
I demonstrate problem-solving on the white board & 3.53 & 0.75 \\
I lay emphasis on mathematical presentation of concepts & 3.82 & 0.96 \\
I lay emphasis on qualitative thinking and presentation of concepts & 3.86 & 3.73 \\
I use demonstrations and discussions to illustrate concepts/phenomena & 2.79 & 0.81 \\
Teaching and learning is teacher directed & 3.28 & 0.86 \\
Teaching and learning is student directed & 3.28 & 0.63 \\
I use students suggestions and ideas in teaching & 3.27 & 0.77 \\
I engage students in context based-activities & 3.25 & 0.77 \\
Students work with physics problems individually & 3.60 & 0.67 \\
Students work with physics problems in groups & 3.30 & 0.62 \\
Students have opportunity to explain their own ideas & 2.55 & 0.77 \\
Students do experiment by following instructions from the teacher & 3.39 & 0.75 \\
Students plan and do their own experiment & 0.85 \\
\hline Average scores & 0.76 \\
\hline
\end{tabular}

As can be seen in Table 1, the teachers use a variety of teaching approaches in their physics classrooms. The overall mean score and standard deviation on this subscale were: $\underline{M}=3.39$ and $\underline{\mathrm{SD}}=0.76$. This gives an indication that physics teachers 'sometimes' use the named teaching strategies. An examination of the individual items shows that teachers most of the time use the white board for classroom instruction $(\underline{\mathrm{M}}=3.89, \underline{\mathrm{SD}}=$ $0.75)$. Teachers also seemed to use demonstration and discussion to illustrate concept/phenomena most of the time $(\underline{\mathrm{M}}=3.86, \underline{\mathrm{SD}}=0.73)$. Teacher-centred approaches were prevalent in most physics classrooms $(\underline{\mathrm{M}}=3.73$, $\underline{\mathrm{SD}}$ 0.86). Students' ideas and suggestions were not often used in teaching $(\mathrm{M}=2.79, \mathrm{SD}=0.63)$. In addition, students were seldom given opportunities to plan and carry out their own experiments $(\underline{\mathrm{M}}=2.55, \underline{\mathrm{SD}}=0.85)$ and more often they would perform experiments by following teachers' instructions.

The findings in Figure 3 show that students generally agreed with the teachers on many points about how often the teaching strategies and practices were applied. For example, students had few opportunities to plan and carry out their own experiments. Teaching and learning was more teacher-centred than student-centred. An examination of students experiences in relation to what actually happened in their classroom and how often they would prefer the strategies to be applied reveal that students were dissatisfied with many of the teaching approaches used.

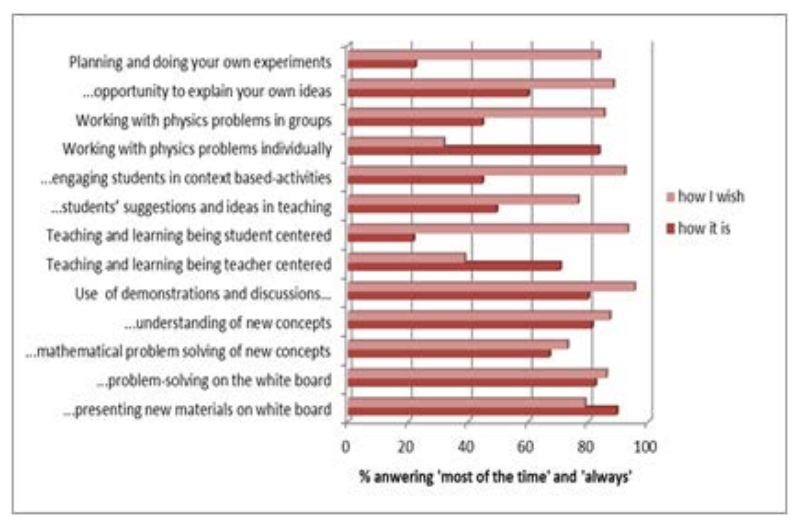

Figure 3. Students' responses about teaching approaches

The teacher feedback and guidance sub-scale was used to find out how physics teachers relate, encourage, motivate and show interest in their students' learning. The mean scores and standard deviations of the responses are presented in Table 2.

Table 2. Means and standard deviations of items on Teacher Feedback and Guidance

\begin{tabular}{|c|c|c|}
\hline Statements & Mean & Std. dev. \\
\hline Tell students how they can improve their performance & 3.94 & 0.68 \\
\hline Give quizzes that I mark to see how students are performing & 2.89 & 0.80 \\
\hline Talk to students on how they are getting on in physics & 3.68 & 0.80 \\
\hline Mark students' work and give it back quickly & 3.97 & 0.81 \\
\hline Use language that is easy to understand & 4.24 & 0.63 \\
\hline Show students how new concepts in physics relate to what we have already done & 4.11 & 0.76 \\
\hline Average scores & 3.81 & 0.75 \\
\hline
\end{tabular}


The overall mean score and standard deviation for the teachers on teacher feedback and guidance were: $\underline{M}=3.81$ and $\underline{\mathrm{SD}}=0.75$ respectively. This indicates that teachers in the survey perceived their response and assistance to students to be important. That is, most of the time, teachers in the survey showed interest in their students' learning and provided the needed motivation and encouragement to students. The item "I use language that is easy to understand" $(\underline{\mathrm{M}}=4.24, \underline{\mathrm{SD}}=0.63)$ and "show students how new concepts relate to what we have already done" $(\underline{M}=4.11, \underline{S D}=0.76)$ for example, were rated very highly. On the other hand, formative types of assessment in classrooms, such as giving quizzes and marking these to see how students are performing rarely occurred $(\underline{\mathrm{M}}=$ 2.89, SD 0.80).

Figure 4 shows that students agreed with the teachers for almost all of the items on the teacher feedback and guidance sub-scale. The majority of the students (84\%) indicated that their teacher's use of language was easy to understand. About $75 \%$ also stated that teachers often showed them how new concepts related to what they had done already. The students perceived that teachers did not talk to them about how they were getting on in physics as often as purported by the teachers. It was the wish of the majority (92\%) of the students that teachers showed interest in their learning by having discussions with them about their performance in physics. The majority of the students (about 90\%) would also like to have formative types of assessment in the classroom so that they can assess how they are performing in the subject.

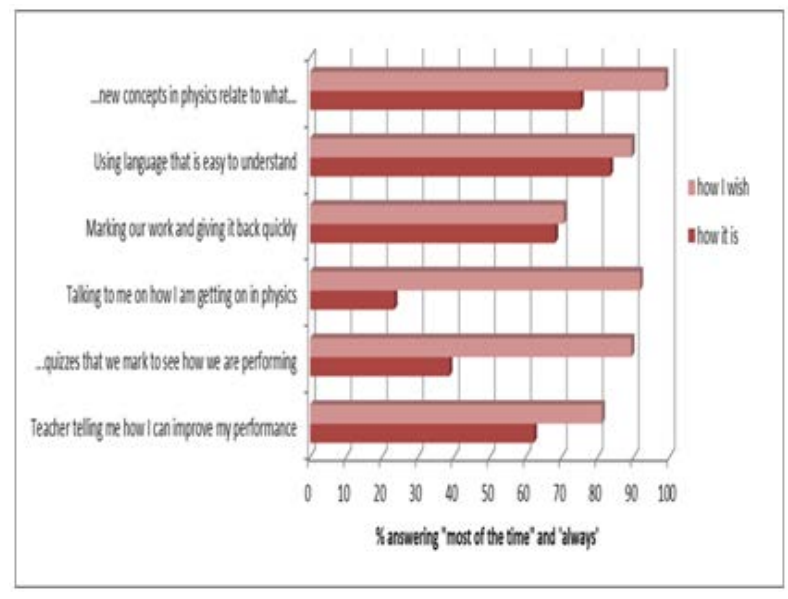

Figure 4. Students responses about teacher feedback and guidance

The third sub-scale, ICT usage in physics teaching, was used to find out how often physics teachers use ICT tools to enhance student learning. As shown in Table 3, the mean scores for all five questions related to the use of ICT indicated that the majority of physics teachers used ICT tools sporadically or rarely at all.

Table 3. Means and standard deviation of items on ICT Usage in Physics Teaching

\begin{tabular}{lll}
\hline Statements & Mean & Std. dev. \\
\hline Use computers for laboratory simulations & 2.83 & 0.88 \\
We look for information on the internet at school & 2.88 & 0.83 \\
Use computers to collect and/or analyze data & 2.50 & 0.91 \\
Use computers to demonstrate physics principles & 2.92 & 0.68 \\
Students use their phones to search for information at school & 2.31 & 0.98 \\
\hline Average scores & 2.67 & 0.86 \\
\hline
\end{tabular}

Likewise, students in the survey confirmed that ICT tools were rarely used in the teaching and learning of physics, as shown in Figure 5. Looking at the differences between "how it is" and "how I wish" for the usage of ICT tools, it can be said that students were generally dissatisfied with the current situation. A change in teaching strategies to involving ICT tools in teaching physics is thus desirable.

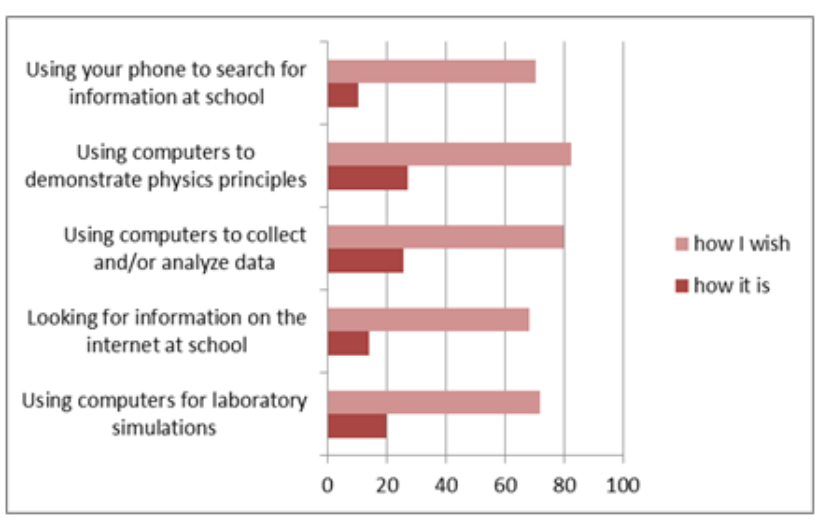

Figure 5. Students responses about ICT usage in physics teaching

\subsection{Suggested Changes to Make Physics More Interesting to Learn}

The teachers who participated in the survey believed that several factors hinder the quality teaching and learning of physics at high school and that these factors may contribute to declining student interest in the subject. Chief amongst these limiting factors were: assessment demands; curriculum and time-tabling; limited access to physics teaching at junior science level; teacher factors and pedagogy; the perceived nature of physics; poor student mathematical literacy; and low salary/lack of incentives for teachers to enter the profession. Many teachers believed that physics teaching in New Zealand is driven by assessment, not by student interests, and that schools place too much emphasis on performance and grades. The teachers felt that their ability to focus on improving teaching and learning was compromised by the time spent addressing assessment requirements. One teacher stated:

We race through the curriculum to be ready for the exam, there is no time to 'teach' physics, no time to experiment with concepts and practise, teaching contents especially. 3.6 (Demonstrate understanding of electrical systems) is pretty dry and that is putting many students off. (Physics teacher).

The teachers bemoaned the fact that the junior science does not provide adequate preparation for students to successfully pursue physics at senior high school level. They observed that because of the integrated way junior science is taught, some students may not meet a physics teacher until quite late in their schooling, when they have already made subject or career choices. They further 
indicated that they believed junior science was often taught by biology specialists who sometimes appeared to have little knowledge and interest in physics. One teacher remarked:

Progression of physics through lower levels being taught by non-physicists is a major problem. Often students come to senior physics with misconceptions from learning physics in junior school by teachers not having adequate physics knowledge.(Physics teacher).

In the responses to their questionnaire, some teachers indicated the extent to which they felt changes needed to occur that would help improve the teaching and learning of high school physics and increase the numbers of students taking the subject. Their responses were coded and ranked on a five-point Likert scale from 1(strongly disagree) to 5(strongly agree). In addition, an open-ended question asked the teachers to suggest ways for improving the teaching and learning of physics and increase the numbers of students wanting to be educated as physics teachers. Table 4 provides a summary of percentage and mean scores of the teachers' responses to the perceived changes.

As seen in Table 4, all the changes were rated positive (high) by the teachers as all items recorded a mean score of 3.5 or above. About $80 \%$ of the teachers believed that, to improve the quality of physics teaching and learning and to increase teacher numbers, more physics graduates should be encouraged and supported to train as teachers. This item had a mean score of 4.01 and standard deviation of 0.93.In addition, the teachers would like of to see more physics cluster meetings where they collaborate and share ideas about physics teaching, about $82 \%$ perceived this as a positive (mean score of 4.00 ) change.

Table 4. Percentage and Mean Scores of Perceived Changes for Improving Teaching andLearning of Physics

\begin{tabular}{|c|c|c|c|c|c|c|c|}
\hline \multirow{2}{*}{ Perceived factors } & \multicolumn{5}{|c|}{ Percentage responses $(\mathrm{N}=104)$} & \multirow{2}{*}{ Mean } & \multirow{2}{*}{$\begin{array}{l}\text { Std. } \\
\text { dev. }\end{array}$} \\
\hline & SA & A & NS & $\mathrm{D}$ & $\mathrm{SD}$ & & \\
\hline Better pre-service education & 10.6 & 47.1 & 28.8 & 12.5 & 1.0 & 3.54 & 0.88 \\
\hline Physics cluster meetings to share ideas about physics teaching & 22.1 & 59.6 & 15.4 & 1.9 & 1.0 & 4.00 & 0.74 \\
\hline More teacher professional development on physics practicals & 19.2 & 57.7 & 16.3 & 5.8 & 1.0 & 3.88 & 0.82 \\
\hline More physics graduates encouraged and/or supported to be trained as teachers & 32.7 & 44.2 & 16.3 & 4.8 & 1.9 & 4.01 & 0.93 \\
\hline Reduction in assessment changes from NZQA and MOE & 23.1 & 35.6 & 24.0 & 16.3 & 1.0 & 3.63 & 1.04 \\
\hline
\end{tabular}

SA-Strongly Agree; A-Agree; NS-Not Sure; D-Disagree; SD-Strongly Disagree.

About $72 \%$ of teachers indicated that better remuneration for physics teachers would help improve the teaching of physics, the numbers of students who want to study physics beyond high school level, and the numbers of physics graduates wanting to become teachers.

The open-ended question which asked teachers to suggest ways for improving the teaching and learning of senior physics and to increase the numbers of students taking the subject yielded 98 individual responses. The suggestions for improvement provided by the teachers fell into the categories shown in Table 5. The most common suggestions for improvement by the teachers included reducing curriculum content and assessment requirements (30.6\%); better salary and support for physics teachers (21.4\%); having more qualified physics teachers (17.3\%); professional learning on subject matter content knowledge (15.3\%); and good physics and mathematics teaching at junior school level (15.3\%).

Table 5. Physics Teachers Suggestions for Improving Teaching and Learning of Senior Physics ( $\mathbf{N}=\mathbf{9 8})$

\begin{tabular}{lll}
\hline Category & $\mathrm{N}$ & $\%$ \\
\hline Improved salary and support & 21 & 21.4 \\
Curriculum content and assessment requirements & 30 & 30.6 \\
Improved physics and mathematics tuition at junior level & 15 & 15.3 \\
Professional development on content knowledge & 15 & 15.3 \\
More qualified physics teachers & 17 & 17.3 \\
\hline
\end{tabular}

\subsection{Students' Perceptions of Physics}

The students' interviews centered on physics teaching and learning, their interest and achievement in physics and why they would or would not want to become physics teachers. Fourteen focus group interviews were conducted with a total of 82 students. When responding to: "Do you enjoy physics lessons and what helps you to enjoy or not enjoy Physics lessons?" about three quarters of the students mentioned that they enjoyed physics lessons and found them interesting and fun when the content related to the real world. They also thought that sometimes the lessons were uninspiring, making the subject boring. Some students only enjoyed physics when they understood what was being taught, otherwise they became confused and didn't like it. Others also indicated that they didn't particularly enjoy physics lessons because the content was too difficult for them.

I enjoy it if I get it, if I get what it is we're doing in class, but if I don't I'm just confused and don't really get it. (Girl, Year 12)

If I understand it then I seriously enjoy physics, but if I don't understand anything I think I just shut down and sit there a bit confused. (Boy, Year 13)

About three-quarters of the students stated that they were unhappy with their performance in physics. Almost everyone cited the difficulty, nature of physics and teaching approaches as the reasons for their poor performance. When asked what makes learning physics difficult, students strongly emphasised that physics is difficult to learn because of the inherent nature of the subject: many concepts, numerous formula (equations), different forms of symbolic representation, and the mathematics was confusing.

I think it's just all the formulas and the equations because some of them are quite similar so it's just getting the hang of which is which. There's lot of concepts in it too, sort of if there's two similar concepts you're not sure which one to use, so it could be a bit confusing. (Girl, Year 12).

Another student stated:

In physics we have to think about those things we can't see. Like the magnetic fields and current, and you get 
confused when you actually have to think and imagine about things you don't actually see. (Girl, Year 13).

The students were convinced that encountering these challenges was inevitable when studying physics. They perceived the only options available to them were to either put in more effort to overcome the difficulties or to discontinue taking the subject. Most students indicated they would not take physics as a subject at university but might take "physics-enriched" subjects like engineering, medicine, and health sciences because of the career prospects. Some students indicated that if tertiary level physics was more enjoyable than it was at high school, then they would be interested in taking it, but they had heard that physics becomes more difficult to understand at university. Of the 82 students interviewed, only five (6\%) considered they might become physics teachers at some point in their life.

On how the students would like their physics teachers to change his/her teaching styles to make physics more interesting to learn, most of the students commented that the teaching was "dry" most of the time and this made the subject boring. They proposed having more group activities and discussions so that they could interact with and learn from their peers. Students also wanted more practical and hands-on activities, they saw this as making physics more enjoyable and interactive, thereby making physics interesting to learn.

I think more group activities and classroom discussions so that we could work off each other's strengths and weaknesses to achieve better results in the class. (Boy, Year 13).

The students stated that their interest in physics might be enhanced if physics lessons included smaller group work, where they might be given lots of practice questions and more time to discuss physics problems between and among themselves. In their view, they spent too much time copying the teacher's notes.

\section{Discussion and Implication}

The flow of people moving into physics teaching as a career needs to be addressed urgently. It seems that "the plug is out" in terms of students aspiring to a career in physics teaching. The "tap is also half on" in terms of the flow of students pursuing physics study. This could in part be because there is a perceived lack of student-centred instructional approaches. In New Zealand the assessment system for physics values recall of content knowledge and therefore this is what teachers focus on. The use of more traditional teaching approaches for physics contributes to students thinking that physics is a difficult subject and not something they want to participate in further. Some students in this study took physics because it is a requirement for future qualifications such as for engineering or medicine. As many other authors have noted, physics would potentially be more interesting to learn through a range of more student-centred approaches and the incorporation of different approaches such as the use of modelling, animations and simulations for problem solving (Afra et al., 2009; Akerson et al., 2007; Campbell et al., 2011; Dünser et al., 2012; Pedersen, 2011; Tversky et al., 2002; Ülen \& Gerlič, 2012).
The findings from this study conducted with a wide range of teachers throughout New Zealand align with those of other international studies. It indicates that physics classroom dialogue tends not to support constructivist epistemology or inquiry based teaching and learning. This is contrary to the aspirations of the NZ national curriculum. Student-centred instructional approaches were not common in many physics classes. In most cases, teachers decided on what happened in the classroom and students' ideas and suggestions played little role in the planning of teaching and learning processes. Also, students rarely had the opportunity to plan and implement their own designs for experiments. Similar findings were made by Angell et al.(2004), Hackling et al. (2001), Masika (2011) and Vosniadou (2007) who observed that physics classroom teaching was dominated by teacher-centred approaches and chalk and talk instruction.

As observed by Darling-Hammond and BaratzSnowden (2005) and Smart and Marshall (2012), the range of information and thinking skills students may learn is largely influenced by the types of classroom practices adopted by the teacher and therefore the learning experiences they afford. Perhaps, if teachers used students' prior knowledge and thinking skills to inform students' learning, the students might show more interest in physics. Again, learning is largely influenced by the way students interact in the classroom - through pedagogies involving full interaction, collective reflection and development of consensual knowledge (Conner, 2014a; Darling-Hammond \& Baratz-Snowden, 2005; Moraru et al., 2011; Smart \& Marshall, 2012). Physics teachers therefore need to design and implement instructional approaches that allow students to learn from each other. More so, students in the focus group called for more group activities and discussions, and hands-on activities which will create a platform to learn from each other's strengths and weaknesses to achieve better results. This may result in students' developing positive attitudes for physics and wanting to pursue further studies in physics at higher levels of their education.

The teachers admitted that most students could not see physics as a relevant science because the subject was often taught in a way that did not connect physics concepts with everyday situations. They also conceded that physics teaching was often very traditional, using the chalk and talk approach. These findings align with the students' assertion that physics teaching is often "dry and boring". Teachers' love for and continual usage of this traditional instructional approach may be due to their own experiences at school, both as students and as pre-service teachers.

Teachers of science often teach in the way they were taught (see for example Blanton, 2003; Koballa et al., 2005; Ladachart, 2011; McDermott \& Shaffer, 2000). As noted by the students, physics is naturally not an easy subject and it involves multiple concepts and mathematics that can make it challenging for students. The responsibility lies with physics teachers to create an enabling atmosphere in their classrooms that would allow physics students to lean more and develop greater interest in the subject. As Conner (2013) pointed out, changes to teaching methods are likely to have positive impact on student learning. 
The revelation that physics teachers in this study rarely used ICT tools for physics teaching was disconcerting and should be an area for future professional development for teachers. Professional learning programmes should support teachers to deepen their pedagogical content knowledge to make learning for their students interesting and relevant. Teachers' lack of use of interactive instructional approaches (Dünser et al., 2012; Ülen \& Gerlič, 2012; Wieman et al., 2008) in physics classrooms on a frequent and regular basis may largely be attributed to the limiting factors identified by the teachers. It is possible that most of the teachers are not adequately resourced to use ICT tools, a situation one cannot blame the teachers for creating. It can also be inferred from the findings that amidst other factors there is pressure on teachers to complete assessments tasks. In addition to this is the general lack of status and recognition for the teaching profession. If physics teachers are to maintain a commitment to their subject and deliver quality teaching and learning opportunities to their students then their (teachers) skills and true value must be recognised. They would be motivated by better salary and incentives that are at least equivalent to that earned in competing and potentially appealing alternative professions. Given that most of the physics students in this study did not want to become physics teachers (but rather wanted to be in highly paid jobs like Engineering), there is clearly not a sufficient "pipeline” for supplying physics teachers in the future.

There is reason to believe that some students are taught physics, especially in the junior high school, by teachers not qualified to do so and who for one reason or another switched to physics teaching from other subjects. These teachers often do not have sufficient physics content knowledge, which may disadvantage their students. Such students are likely to experience poor physics teaching and so not be motivated to pursue physics study. Teachers and students indicated that there is unequal access to physics education at the junior science level, depending on the background of their teachers. There seems to be more biology teachers teaching junior science in New Zealand schools and the attitude of these teachers to physics may be a negative determinant of student interest in the subject. If these teachers hold negative opinions of physics, don't understand it or don't have a passion for teaching it, then students may quickly conclude that the subject is irrelevant, too difficult to master or boring. This has probably contributed to lower numbers of students choosing physics and possibly lower achievement as well. It is reasonable to surmise that the lack of subject specialists has created this situation over a number of years.

Current assessment practices and high teacher workloads seem to have eroded time that physics teachers would otherwise use to prepare interesting lessons and to engage in professional development. The emphasis placed on high stakes assessment for senior students should be reviewed so that teachers can spend more time 'teaching' and helping students to learn.

Some possible ways to increase the number of physics teachers might include partnerships between stakeholders and businesses to provide scholarships for people who have majored in physics to become teachers and for people with physics related careers who could be diverted into teaching through such incentives. Part-time pathways for initial teacher education might assist potential physics teachers to transition from the workplace. We conclude by making an appeal to the higher authorities and stakeholders of education to make a concerted effort to support and educate more physics graduates for the classroom.

\section{Acknowledgement}

This study was supported by University of Canterbury Doctoral Scholarship, a support which we gratefully acknowledge. We would also want to thank Sabina Cleary and Judith Bennetts (UC Education Plus) for support and input.

\section{References}

[1] Afra, N., Osta, I., \& Zoubeir, W. (2009). Students' alternative conceptions about electricity and effect of inquiry-based teaching strategies. International Journal of Science \& Mathematics Education, 7(1), 103-132.

[2] Akerson, V. L., Hanson, D. L., \& Cullen, T. A. (2007). The influence of guided inquiry and explicit instruction on k-6 teachers' views of nature of science. Journal of Science Teacher Education, 18(5), 751-772.

[3] Angell, C., Guttersrud, Ø., Henriksen, E. K., \& Isnes, A. (2004). Physics: Frightful, but fun. Pupils' and teachers' views of physics and physics teaching. Science Education, 88(5), 683-706.

[4] Archibald, S. (2006). Narrowing in on educational resources that do affect student achievement. Peabody Journal of Education, 81(4), 23-42.

[5] Best, J., \& Kahn, J. (2005). Research in education (10th ed.). Boston: Pearson Education, Inc.

[6] Blanton, P. (2003). Constructing knowledge. The Physics Teacher, 41(2), 125-126.

[7] Blickenstaff, J. C. (2010). A framework for understanding physics instruction in secondary and college courses. Research Papers in Education, 25(2), 177-200.

[8] Bogdan, R., \& Biklen, S. (2007). Qualitative research for education: An introduction to theory and practice (5th ed.). New York: Pearson Education, Inc.

[9] Cahyadi, M. V. (2007). Improving teaching and learning in introductory physics. Doctoral dissertation, University of Canterbury, Christchurch.

[10] Campbell, T., Danhui, Z., \& Neilson, D. (2011). Model based inquiry in the high school physics classroom: An exploratory study of implementation and outcomes. Journal of Science Education \& Technology, 20(3), 258-269.

[11] Cobern, W. W. (1998). Socio-cultural perspectives on science education: An international dialogue (Vol. 4): Springer.

[12] Cohen, L., Manion, L., \& Morrison, K. (2007). Research methods in education (6th ed.). New York: Routledge.

[13] Conner, L. (2013). Meeting the needs of diverse learners in New Zealand. Preventing School Failure: Alternative Education for Children and Youth, 57(3), 157-161.

[14] Conner, L. (2014a). Students' use of evaluative constructivism: comparative degrees of intentional learning. International Journal of Qualitative Studies in Education, 27(4), 472-489.

[15] Conner, L. (2014b). IMSS 2011: School principals' actions and preparedness of grade 8 science teachers in four east asian school systems. In O. S. Lan, E. Gonzalez \& S. K. S. Shanmugam (Eds.), TIMSS 2011: What can we learn together? (pp. 21-37). Penang: South East Asian Ministries of Education Organisation.

[16] Creswell, J. W., \& Clark, V. L. P. (2011). Designing and conducting mixed methods research (2nd ed.). Thousand Oaks, CA: Sage Publications.

[17] Darling-Hammond, L., \& Baratz-Snowden, J. (2005). A good teacher in every classroom: Preparing the highly qualified teachers our children deserve. San Fransisco, CA: John Wiley and Sons, Inc.

[18] Driver, R., Asoko, H., Leach, J., Scott, P., \& Mortimer, E. (1994). Constructing scientific knowledge in the classroom. Educational researcher, 23(7), 5-12. 
[19] Dünser, A., Walker, L., Horner, H., \& Bentall, D. (2012, November 26-30). Creating interactive physics education books with augmented reality. Paper presented at the Proceedings of the 24th Australian Computer-Human Interaction Conference Melbourne, Victoria.

[20] Education Review Office. (2012). The New Zealand curriculum principles: Foundations for curriculum decision-making. Wellington: Education Review Office.

[21] Fraenkel, J. R., Wallen, N. E., \& Hyun, H. H. (2012). How to design and evaluate research in education (8th ed.). New York: McGraw-Hill.

[22] Gallagher, J. J. (1991). Prospective and practicing secondary school science teachers' knowledge and beliefs about the philosophy of science. Science education, 75(1), 121-133.

[23] Golla, E. F., de Guzman, E. S., Ogena, E., \& Brawner, F. (1998). Teacher preparation in science and mathematics education: A situational analysis. Science education in the Philippines: Challenges for development, 1, 41-77.

[24] Gray, D. E. (2009). Doing research in the real world (2nd ed.). Thousand Oaks, California: SAGE Publications Inc.

[25] Hackling, M. W., Goodrum, D., \& Rennie, L. (2001). The state of science in Australian secondary schools. Australian Science Teachers' Journal, 47(4), 6-17.

[26] Hake, R. R. (1998). Interactive-engagement versus traditional methods: A six-thousand-student survey of mechanics test data for introductory physics courses. American journal of Physics, 66(1), 64-74.

[27] Institute of Physics [IOP]. (2010). Physics and: teacher numbers. Report of the Institute of Physics, Uk. Retrieved July 7, 2014, from http://www.iop.org/news/10/sep10/file_44832.pdf.

[28] Keser, Ö. F., Akdeniz, A. R., \& Yyu, V.-T. (2010). Assessment of the constructivist physics learning environments. Paper presented at the Asia-Pacific Forum on Science Learning and Teaching.

[29] Koballa, T. R., Glynn, S. M., \& Upson, L. (2005). Conceptions of teaching science held by novice teachers in an alternative certification program. Journal of Science Teacher Education, 16(4), 287-308

[30] Ladachart, L. (2011). Thai physics teachers' conceptions about teaching. Journal of Science and Mathematics Education in Southeast Asia, 34(2), 174-202.

[31] Lewis-Beck, M. S., Bryman, A., \& Liao, T. F. (Eds.). (2004). The Sage encyclopedia of social science research methods (3rd ed.). Thousand Oaks, California: Sage Publications Inc.

[32] Loucks-Horsley, S., Stiles, K. E., Mundry, S., Love, N., \& Hewson, P. W. (2010). Designing professional development for teachers of science and mathematics. Thousand Oaks, California: Corwin.

[33] Masika, M. W. (2011). Classroom interaction patterns of teachers of physics in secondary school in Nairobi province, Kenya. Master's Thesis, Kenyatta University, Nairobi.

[34] May, T. (2001). Social research: issues, methods and process. Buckingham: Open University.

[35] McDermott, C. L., \& Redish, E. F. (1999). Resource letter: PER-1: Physics education research. American Journal of Physics, 67, 755767.
[36] McDermott, C. L., \& Shaffer, P. S. (2000). Preparing teachers to teach physics and physical science by inquiry. Physics Education, 35(6), 411-416.

[37] Ministry of Education. (2007). The New Zealnd curriculum Wellington Learning Media Limited.

[38] Moraru, S., Stoica, I., \& Popescu, F. F. (2011). Educational software applied in teaching and assessing physics in high schools. Romanian Reports in Physics, 63(2), 577-586.

[39] Mulhall, P., \& Gunstone, R. (2008). Views about physics held by physics teachers with differing approaches to teaching physics. Research in Science Education, 38(4), 435-462.

[40] Mulhall, P., \& Gunstone, R. (2012). Views about learning physics held by physics teachers with differing approaches to teaching physics. Journal of Science Teacher Education, 23(5), 429-449.

[41] National Research Council. (1996). National science education standards: Observe, interact, learn. Washington DC: National Academo Press.

[42] NVivo qualitative data analysis software; QSR International Pty Ltd. Version 10, 2012.

[43] Pedersen, H. (2011). Learning with animation. Journal of Assistive Technologies, 5(1), 35-37.

[44] PhysTEC. (2014). Specific indicators of the need for qualified physics teachers. Retrieved July 8, 2014, from http://www.phystec.org/webdocs/shortage.cfm.

[45] Redish, E. F., \& Steinberg, R. N. (1999). Teaching physics: Figuring out what works. Physics Today, 52, 24-31.

[46] Sarantakos, S. (2005). Social research (3rd ed.). New York: Palgrave Macmillan.

[47] Smart, J. B., \& Marshall, J. C. (2012). Interactions between classroom discourse, teacher questioning, and student cognitive engagement in middle school science. Journal of Science Teacher Education, 249-267.

[48] Taylor, B. A. (2004). The influence of classroom environment on high school students' mathematics anxiety and attitudes. $\mathrm{PhD}$ Thesis, Curtin University of Technology, Perth.

[49] Thacker, B. A. (2003). Recent advances in classroom physics. Reports on progress in physics, 66(10), 1833-1864.

[50] Tobin, K., \& Gallagher, J. J. (1987). What happens in high school science classrooms? Journal of Curriculum Studies, 19(6), 549560.

[51] Tversky, B., Morrison, J. B., \& Betrancourt, M. (2002). Animation can it facilitate? International Journal of Human-Computer Studies, 57(4), 247-262.

[52] Ülen, S., \& Gerlič, I. (2012). The conceptual learning of physics in slovenian secondary schools. Organizacija, 45(3), 140-144.

[53] Vosniadou, S. (2007). Conceptual change and education. Human Development, 50(1), 47-54.

[54] Weiss, I. R., Banilower, E. R., McMahon, K. C., \& Smith, P. S. (2001). Report of the 2000 national survey of science and mathematics education. Chapel Hill, NC: Horizon Research, Inc.

[55] Wieman, C. E., Perkins, K. K., \& Adams, W. K. (2008). Oersted medal lecture 2007: Interactive simulations for teaching physics: What works, what doesn't, and why. American Journal of Physics, 76, 393.

[56] Yin, R. K. (2009). Case study research: Design and methods (4th ed.). Los Angeles: Sage. 